\title{
УДОСКОНАЛЕННЯ ПУБЛІЧНО-СЕРВІСНОЇ ДІЯЛЬНОСТІ СИСТЕМИ МВС УКРАЇНИ В УМОВАХ ДЕЦЕНТРАЛІЗАЦІЇ
}

\author{
Циганов О. Г., Дрозд В. Г.
}

\section{ВСТУП}

Конституція України проголошує Україну демократичною, соціальною й правовою державою, зміст і спрямованість діяльності якої визначають права і свободи людини та забезпечення їх гарантії. Тому модернізація всієї системи публічного адміністрування в Україні повинна бути спрямована передовсім на запровадження нової ідеології функціонування органів публічної влади як діяльності щодо забезпечення реалізації прав, свобод і законних інтересів приватних осіб, надання їм якісних і доступних адміністративних послуг. Поряд із цим сьогодні цільовими орієнтирами реформування місцевого самоврядування й територіальної організації влади в Україні є сталий розвиток територій і самодостатність територіальних громад, наближення якості послуг регіональних органів публічної влади до міжнародних, зокрема європейських, стандартів.

Важливий складник у системі органів публічної влади України, що потребує реформування на шляху реалізації ідеї сервісної держави, становлять органи й підрозділи системи МВС України. Разом зі сталим розвитком української державності, процесом соціалізації всіх сфер життєдіяльності суспільства закономірно відбувається еволюція соціально-правової орієнтації цих державних органів й механізму реалізації їхньої компетенції. Наразі переглядаються й визначаються сучасні місце та роль цих органів у механізмі держави України, відбувається переорієнтація їх діяльності на соціальний складник, усе чіткіше проявляється іiі новий напрям - публічно-сервісний, який полягає в наданні послуг суспільству та окремим його членам у межах здійснення правоохоронної діяльності.

Хоча останніми роками питання впорядкування системи надання адміністративних послуг набуло актуальності на вищому державному рівні, сьогодні діяльність із надання адміністративних послуг, зокрема, у сфері внутрішніх справ залишається не досить ефективною, якість цієї діяльності не повною мірою відповідає інтересам i прагненням населення. Стратегічними напрямами для подальшої реформи публічносервісної діяльності, які повинні підвищити якість і зручність одержання послуг споживачами, експерти визначають широке використання в цій 
діяльності принципів субсидіарності та децентралізації, впорядкування відносин щодо оплати адміністративних послуг, загальну дерегуляцію або спрощення процедури надання послуг.

\section{1. Системність і послідовність реформ у сфері публічно-сервісної діяльності як запорука стійкого підвищення} якості адміністративних послуг

В умовах сьогодення надання адміністративних послуг є тією сферою діяльності органів публічної влади та їхніх посадових осіб, 3 якою найчастіше стикається кожен громадянин країни. Тому ініціативи публічної адміністрації за напрямом підвищення якості та доступності послуг, що надаються населенню, є дуже важливими для споживачів, слугують позитивній зміні уявлення громадськості про державну службу, підвищують довіру громадян до владних органів.

Якість будь-якої послуги, зокрема, й у сфері внутрішніх справ полягає в їі здатності завдяки сукупності невіддільних властивостей і певних, заздалегідь визначених характеристик відповідати очікуванням і вимогам (потребам) споживачів та інших заінтересованих сторін як під час проходження процедури отримання самої послуги, так і під час використання іiі результату. Щоб контролювати якість послуги та забезпечувати належний рівень цієї якості, необхідно мати можливість здійснювати оцінку якості відповідної послуги.

Під оичнкою якості послуги (обслуговування) слід розуміти кількісне або якісне визначення ступеня відповідності показника якості послуги (обслуговування) офіційно встановленим вимогам або очікуванням споживачів. При цьому під показниками якості послуги (обслуговування) розуміються кількісні або якісні характеристики однієї або декількох властивостей послуги (обслуговування), що визначають іiі (його) якість, які розглядаються стосовно певних умов надання послуги та дають можливість їх вимірювання, оцінки та перевірки ${ }^{1}$.

Опитування, проведене в листопаді 2015 року Фондом «Демократичні ініціативи» імені Ілька Кучеріва спільно із соціологічною службою Центру Разумкова, показало, що якість надання адміністративних послуг в Україні загалом позитивно оцінювали лише $14 \%$ населення (для порівняння: у 2014 році - $5 \%$ ). Водночас частка тих, хто вважав якість надання послуг поганою, становила 32 \%

${ }^{1}$ Циганов О. Питання категоріально-понятійного апарату правового інституту «адміністративна послуга». Вісник Національного технічного університету Украӥни «Київький політехнічний інститут». Політологія. Соціологія. Право : зб. наук. пр. Київ : НТУУ «КПІ», 2012. № 2 (14). С. 126-132. 
(у 2014 році - $40 \%$ ), ще $37 \%$ оцінювали надання адміністративних послуг задовільно - приблизно на рівні 2014 року (35\%).

Найбільш позитивними елементами під час надання адміністративних послуг респонденти під час зазначеного опитування назвали такі: чіткі пояснення щодо всіх обставин справи та потрібних документів (26\%), коректність поведінки посадових осіб (майже $20 \%$ ), а також зручні години прийому (15\%). Серед основних негативних моментів під час надання адміністративних послуг респонденти найчастіше зазначали таке: великі черги (28 \%), тяганину з розглядом справи (більш ніж $21 \%$ ), відсутність чітких пояснень щодо потрібних документів і необхідність відвідувати установи кілька разів (18 \%), а також необхідність ходити до інших інстанцій (13\%).

Опитування 2015 року засвідчило, що давати хабарі (зокрема, гроші, надання послуг у відповідь, дарунки тощо) задля отримання адміністративних послуг доводилося упродовж останніх 12 місяців майже $12 \%$ населення (у 2014 році цей показник становив $11 \%$ ). При цьому хабарі більшою мірою мали «ініціативний» характер. Зокрема, третина населення зазначала, що люди дають хабарі тому, що «так простіше і легше вирішити їхні проблеми». На другому місці твердження, що хабарі - «це вже норма нашого життя» (так уважали $20 \%$ опитаних). Окрім того, 18 \% населення України вказували, що люди дають хабарі, бо від них їх вимагають.

Головними дієвими засобами в боротьбі з корупцією, зокрема, у сфері адміністративних послуг опитувані у 2015 році вважали заходи карального характеру, а саме: звільнення хабарника з роботи без права обіймати посади в органах влади (62\%) та посилення кримінальної відповідальності чиновників за корупцію (51\%).

Згідно з опитуванням 2015 року суттєвою була орієнтація населення на профілактичні та пов'язані із загальною демократизацією суспільства засоби боротьби з корупцією. Серед названих варіантів найбільше відповідей набрали:

- вдосконалення законодавства й ліквідація шпарин для корупції $30 \%$;

- контроль громадськості за діями влади - $29 \%$;

- широке викриття фактів корупції через ЗМІ - $29 \%$;

- підвищення прозорості та відкритості діяльності органів влади $26 \%$;

- правове виховання громадян - $24 \%$.

У 2015 році більшість респондентів не була знайома 3 діяльністю державної чи місцевої влади у сфері надання адміністративних послуг (52\%), але частка необізнаних щодо цього громадян мала тенденцію до 
скорочення (адже у 2013 році таких було $67 \%$, а у 2014 році - $59 \%$ ). Опитування 2015 року засвідчило також зростання частки й тих, хто знав про створення центрів надання адміністративних послуг (3 $21 \%$ у 2014 році до $25 \%$ у 2015 році) та створення офіційних вебресурсів щодо адміністративних послуг (з $9 \%$ - до $11 \%)^{2}$.

Для демонстрації зростання якості адміністративних послуг в Україні варто навести основні результати загальнонаціонального опитування громадян України щодо якості публічно-сервісної діяльності, яке проводилося Фондом «Демократичні ініціативи» імені Ілька Кучеріва у липні 2019 року. Це опитування засвідчило, що хоча за останні 5 років фактично не змінилася частка громадян України, які оцінюють якість надання адміністративних послуг на задовільному рівні (як і в 2015 році, це ті ж 37 \%), однак сьогодні добру або дуже добру оцінку якості надання послуг поставили майже $19 \%$ респондентів (що на 5 та 14 \% більше, ніж у 2015 та 2014 роках відповідно), а кількість негативних оцінок скоротилась більш ніж удвічі - до $16 \%$. Серед тих респондентів, які безпосередньо зверталися до органів влади за адміністративними послугами, задоволеною залишилася понад половина - 51\%. Раніше, у 2015 році, цей показник становив $42 \%$, а у 2014 році - $30 \%$.

Під час зазначеного опитування респонденти вказали такі основні позитивні аспекти під час отримання адміністративних послуг: посадові особи поводилися коректно й ввічливо; чітке пояснення всіх обставини справи (зокрема, які документи потрібні); у приміщенні органу було вдосталь інформації, необхідної для отримання послуги (зокрема, наявні зразки заповнення документів); було забезпечено зручні та комфортні умови очікування (стільці, місця для заповнення документів тощо). Водночас основні нарікання споживачів передовсім стосувалися великих черг (20\% відповідей), надто довгої тривалості справи та відсутності пояснень, які саме документи були потрібні. При цьому основна проблема - великі черги - стала менш згадуваною порівняно з минулими опитуваннями (із $42 \%$ у 2014 році цей показник зменшився до 20 \%). Позитивна динаміка щодо зменшення «негативних елементів» під час отримання адміністративних послуг має місце фактично й за всіма іншими показниками, якщо порівнювати дані грудня 2014-го і липня 2019 року.

\footnotetext{
${ }^{2}$ Оцінки населенням України якості надання адміністративних послуг (2015 рік, а також порівняння 3 минулими роками). Грудень 2015 р. Фонд «Демократичні ініціативи». URL: https://dif.org.ua/article/otsinki-naselennyam-ukraini-yakosti-nadannyaadministrativnikh-poslug-2015-rik-a-takozh-porivnyannya-z-minulimi-rokami (дата звернення: 18.04.2020).
} 
Водночас суттєво не змінилася ситуація 3 потребою дачі хабара чи інших послуг посадовим особам. 3 такими негативними фактами стикалися майже $9 \%$ із тих осіб, які зверталися за адміністративними послугами. Ще майже $20 \%$ респондентів не захотіли відповідати на це запитання. У попередніх опитуваннях ці показники були на цьому ж рівні.

Головними дієвими засобами в боротьбі з корупцією, зокрема, у сфері публічно-сервісної діяльності населення України й надалі вважає заходи карального характеру: звільнення хабарника з роботи без права обіймати посади в органах влади (59 \%), посилення кримінальної відповідальності чиновників за корупцію (51 \%).

Порівняно з 2015 роком суттєво збільшилась обізнаність громадян із діяльністю державної чи місцевої влади у сфері адміністративних послуг. Зокрема, сьогодні 42 \% респондентів знають про створення центрів надання адміністративних послуг (у 2015 році - $25 \%$ ). Зростання рівня обізнаності, зокрема, пов'язано і зі збільшенням кількості центрів надання адміністративних послуг (далі - ЦНАП). Наприклад, 46 \% опитаних відповіли, що в їхньому місті утворено ЦНАП, у 2015 році таких було $20 \%$, а у 2014-му - лише $13 \%$. При цьому також збільшилась кількість людей, які звертались до ЦНАП, і наразі становить 43 \% від тих, які знають про ЦНАП у своєму місті. У 2013 році цей показник становив $35 \%$. Рівень задоволення послугами ЦНАП їхніми безпосередніми користувачами $є$ досить високим $-82 \%$ опитаних. Крім того, $5 \%$ населення вже користувалися адміністративними послугами онлайн ${ }^{3}$.

Отже, слід погодитися 3 думкою експертів, що реформа адміністративних послуг - одна з найбільш системних і послідовних реформ України у сфері публічного адміністрування. Адже інститут адміністративних послуг було започатковано Концепцією адміністративної реформи, схваленою Указом Президента України від 22 липня 1998 року ${ }^{4}$. Першу комплексну концепцію розвитку системи надання адміністративних послуг було схвалено Урядом України в лютому 2006 року $^{5}$, перший ЦНАП утворено у 2008 році у Вінниці ${ }^{6}$.

3 Якість надання адміністративних послуг в Україні: думка громадян, оцінка фахівців та зміни за 5 років. Фонд «Демократичні ініціативи». URL: https://dif.org.ua/article/yakist-nadannya-administrativnikh-poslug-v-ukraini-dumkagromadyan-otsinka-fakhivtsiv-ta-zmini-za-5-rokiv (дата звернення: 18.04.2020).

${ }^{4}$ Про заходи щодо впровадження Концепції адміністративної реформи в Україні : Указ Президента України від 22 липня 1998 р. № 810/98. Офіиійний вісник України. 1999. № 21. Ст. 943.

5 Про схвалення Концепції розвитку системи надання адміністративних послуг органами виконавчої влади : Розпорядження Кабінету Міністрів України від 15 лютого 2006 р. № 90-р. Офіиійний вісник Украӥни. 2006. № 7. Ст. 376. 
У 2012 році ухвалено Закон України «Про адміністративні послуги» ${ }^{7}$, який дав змогу змінити ідеологію відносин між органами публічної влади та особами приватного права, а також створив умови для впровадження ЦНАП при обласних i районних державних адміністраціях та виконавчих органах місцевого самоврядування ${ }^{8}$.

Водночас, відповідно до Концепції реформування місцевого самоврядування та територіальної організації влади в Україні, покладеної в основу чинної реформи децентралізації й схваленої Розпорядженням Кабінету Міністрів України від 1 квітня 2014 року № 333-р, одним із пріоритетних завдань вказаної реформи визначено забезпечення доступності та якості публічних (зокрема, адміністративних) послуг, що досягається шляхом оптимального розподілу повноважень між органами місцевого самоврядування та органами виконавчої влади на різних рівнях адміністративно-територіального устрою за принципами субсидіарності та децентралізації. Зазначена вимога Уряду стосується також послуг, надання яких належить до компетенції органів i підрозділів системи МВС України.

\section{2. Проблемні питання та напрями реформування адміністративно- правових відносин щодо надання адміністративних послуг у сфері внутрішніх справ України в умовах децентралізації}

Важливим завданням, що потребує розв'язання на будь-якому етапі становлення демократичної правової держави, є забезпечення належного функціонування механізмів захисту прав і охоронюваних законом інтересів фізичних та юридичних осіб приватного права й забезпечення законності у відносинах цих осіб з органами публічної влади, зокрема, у сфері внутрішніх справ. При цьому закріплення демократичних правових стандартів взаємовідносин людини та держави в особі їі органів потребує реформування відповідних адміністративно-правових відносин із метою створення реального механізму забезпечення реалізації прав, свобод i законних інтересів фізичних та юридичних осіб.

6 За 10 років вінницький прозорий офіс прийняв понад 4,5 млн відвідувачів. Офіиійний сайт Вінницької міської ради. 10 жовтня 2018 p. URL: https://www.vmr.gov.ua/ Lists/CityNews/ShowNews.aspx?ID=5446 (дата звернення: 18.04.2020).

${ }^{7}$ Про адміністративні послуги : Закон України від 6 вересня 2012 р. № 5203-VI. Офіиійний вісник України. 2012. № 76. Ст. 3067.

8 Циганов О. Надання адміністративних послуг правоохоронними органами України: організаційно-правові аспекти : монографія. Київ-Вінниця : ТОВ «НіланЛТД», 2018. 456 с. С. 196.

9 Про схвалення Концепції реформування місцевого самоврядування та територіальної організації влади в Україні : Розпорядження Кабінету Міністрів України від 1 квітня 2014 р. № 333-р. Офіиійний вісник Украӥни. 2014. № 30. Ст. 831. 
Суб’єктами адміністративно-правових відносин щодо надання адміністративних послуг у сфері внутрішніх справ $є$ конкретні учасники вказаних відносин, зокрема юридичні та фізичні особи, наділені правами та обов'язками щодо надання та отримання таких послуг - тобто, відповідно, суб'єкти надання адміністративних послуг у сфері внутрішніх справ (ї надавачі) та суб'єкти звернення за отриманням таких послуг (ix одержувачі). Цими суб'єктами виступають органи державного управління в зазначеній сфері та їхні посадові особи, які наділені юридично-владними повноваженнями щодо надання таких послуг. До таких суб'єктів, зважаючи на аналіз правових норм, слід віднести підрозділи та посадові особи таких служб: експертної служби; дозвільної системи, ліцензування та державного охоронного нагляду; Державної міграційної служби України; Державної служби України 3 надзвичайних ситуацій, а також Головний та регіональні сервісні центри МВС. Суб'єктами звернення за отриманням адміністративних послуг у сфері внутрішніх справ слід уважати, відповідно до пункту 1 статті 1 Закону України «Про адміністративні послуги», фізичну або юридичну особу, яка звернулася до суб'єкта надання за отриманням таких послуг ${ }^{10}$.

Об'єктом адміністративно-правових відносин, як відомо, може бути все, що здатне служити задоволенню публічних інтересів. Отже, до об'єктів зазначених правовідносин слід віднести матеріальне або нематеріальне публічне благо (зокрема, матеріальні цінності, духовні та інші соціальні блага, як-от: права людини і громадянина), а також діяння, на використання чи охорону яких спрямовано суб'єктивні права та юридичні обов'язки публічної адміністрації. Наприклад, до об'єктів правовідносин щодо надання адміністративних послуг у сфері внутрішніх справ належать, зокрема, такі нематеріальні блага: право на провадження певного виду діяльності, право на придбання зброї, право виїзду за кордон, право на в”їзд в Україну, право на керування транспортним засобом, дозвіл на рух окремих категорій транспортних засобів тощо. Щодо об'єктів правовідносин у зазначеній сфері як матеріальні цінності можна назвати такі: транспортний засіб, закордонний паспорт, нагородну зброю, посвідчення водія тощо. Також до об'єктів зазначених правовідносин можна віднести адміністративний акт органу чи підрозділу системи МВС України, що засвідчує відповідну правоздатність певних суб'єктів звернення (наприклад, придбавати, зберігати та використовувати наявну у власності зброю). Такий адміністративний акт оформлюється у вигляді документа, який отримує приватна особа, адресат цього акта.

\footnotetext{
${ }^{10}$ Про адміністративні послуги : Закон України від 6 вересня 2012 р. № 5203-VI. Офіиійний вісник України. 2012. № 76. Ст. 3067.
} 
Отже, адміністративно-правові відносини щуодо надання адміністративних послуг у сфері внутрішніх справ можна визначити як врегульовані адміністративно-правовими нормами суспільні відносини, що виникають у зв'язку зі зверненням фізичної чи юридичної особи приватного права до носія владних повноважень у зазначеній сфері органу, підрозділу системи МВС України - 3 приводу прийняття ним адміністративного акта, спрямованого на забезпечення умов для реалізації прав, свобод i законних інтересів зазначеної особи або виконання покладених на цю особу законом обов'язків у сфері внутрішніх справ.

Правовий статус органів і підрозділів системи МВС України як суб'єктів правовідносин щодо надання адміністративних послуг визначається головним чином Законом України «Про адміністративні послуги», a також іншими законодавчими та підзаконними нормативними актами України. При цьому на відносини щодо об'єктів, обмежених у цивільному обігу, зокрема зброї, вказаний Закон не поширюється (п. 13 ч. 2 ст. 2) $)^{11}$.

Крім того, хоча дія Закону України «Про адміністративні послуги» не поширюється на відносини щодо здійснення державного нагляду (контролю), правоохоронним органам надано право в передбачених законом випадках здійснювати контрольно-наглядові (інспекційні) заходи щодо учасників відповідних адміністративно-правових відносин, зокрема відносин у сфері дозвільної системи та ліцензування ${ }^{12}$. Однак випадки поєднання в одній інституції (одному органі влади) функцій із надання адміністративних послуг i контрольно-наглядових (інспекційних) функцій визначено експертами одним із основних корупційних ризиків інституційно-функціонального характеру в системі публічної адміністрації України, пов'язаним із «розмиванням місії» відповідного органу, зменшенням об'єктивності розгляду та перегляду адміністративних справ ${ }^{13}$. Отже, сьогодні залишаються нерозв'язаними питання правоздатності органів і підрозділів системи МВС України, як і інших державних органів, щодо поєднання відповідної контрольнонаглядової діяльності з наданням ними адміністративних послуг.

${ }^{11}$ Про адміністративні послуги : Закон України від 6 вересня 2012 р. № 5203-VI. Офіиійний вісник України. 2012. № 76. Ст. 3067.

12 Про Національну поліцію : Закон України від 2 липня 2015 р. № 580-VIII. Відомості Верховної Ради Украӥни. 2015. № 40-41. Ст. 379; Про затвердження Положення про дозвільну систему : Постанова Кабінету Міністрів України від 12 жовтня 1992 p. № 576. URL: http://zakon4.rada.gov.ua (дата звернення: 11.05.2020).

13 Коліушко І., Тимощук В., Банчук О. та ін. Корупційні ризики надання адміністративних послуг та контрольно-наглядової діяльності в Україні. Центр політико-правових реформ, Фонд «Демократичні ініціативи». Київ : Москаленко О.М. ФОП, 2009. 196 с. С. 14-15. 
Водночас проведений нами аналіз організації публічно-сервісної діяльності у провідних країнах світу засвідчив, зокрема, наявність такої позитивної тенденції, як широке використання принципу субсидіарності, який передбачає процеси децентралізації й делегування повноважень щодо надання адміністративних послуг на найбільш наближений до споживачів рівень й туди, де ці послуги будуть найбільш ефективно надаватися ${ }^{14}$.

Щодо вітчизняних реалій у цьому напрямі слід вказати, що Кабінетом Міністрів України було ухвалено Розпорядження «Деякі питання надання адміністративних послуг органів виконавчої влади через центри надання адміністративних послуг» від 16 травня 2014 p. № 523-р ${ }^{15}$, яке стало важливим кроком за напрямом децентралізації адміністративних послуг в Україні. Відповідно до цього документа надання низки найбільш популярних серед населення адміністративних послуг (зокрема, реєстрація місця проживання особи, оформлення та видача паспорта громадянина України, оформлення та видача або обмін паспорта громадянина України для виїзду за кордон) від органів виконавчої влади мало бути поетапно передано до центрів надання адміністративних послуг у строк до 1 січня 2015 року. Утім, на сьогодні стан реалізації зазначеного урядового рішення не можна вважати задовільним: передачу адміністративних послуг органів виконавчої влади, перелік яких містить розпорядження, до ЦНАП не було забезпечено вчасно та в повному обсязі. Моніторинг запровадження надання адміністративних послуг органів виконавчої влади через ЦНАП, проведений низкою громадських організацій, показав, що нині переважна більшість ЦНАП не надає вичерпного переліку наведених у розпорядженні послуг органів виконавчої влади ${ }^{16}$.

Водночас позитивним досягненням влади стало прийняття Закону України «Про внесення змін до деяких законодавчих актів України щодо розширення повноважень органів місцевого самоврядування та оптимізації надання адміністративних послуг» від 10 грудня 2015 p. № 888-VIII ${ }^{17}$, яким внесено низку змін до деяких законодавчих актів

14 Циганов О. Надання адміністративних послуг правоохоронними органами України: організаційно-правові аспекти : монографія. Київ-Вінниця : ТОВ «НіланЛТД», 2018. 456 с. С. 387.

${ }^{15}$ Деякі питання надання адміністративних послуг органів виконавчої влади через центри надання адміністративних послуг : Розпорядження Кабінету Міністрів України від 16 травня 2014 р. № 523-р. Офіиійний вісник Украӥни. 2014. № 45. Ст. 1193.

16 Проблемні питання децентралізації адміністративних послуг в Україні: аналітична записка Національного інституту стратегічних досліджень. URL: http://www.niss.gov.ua/articles/1797/ (дата звернення: 07.02.2019).

17 Про внесення змін до деяких законодавчих актів України щодо розширення повноважень органів місцевого самоврядування та оптимізації надання 
України, спрямованих на розширення повноважень органів місцевого самоврядування та оптимізацію надання адміністративних послуг. Серед новел цього законодавчого акта - приписи, спрямовані на усунення розбіжностей, що виявлено під час реалізації Закону України «Про адміністративні послуги», шляхом вилучення деяких положень із тексту цього документа та доповнення його новими положеннями, що регулюють статус і діяльність ЦНАП, а також забезпечують удосконалення процедури надання адміністративних послуг в електронній формі. Крім того, органам місцевого самоврядування надано повноваження з надання адміністративних послуг, що мають найбільший попит серед жителів територіальних громад (як-от: щодо реєстрації місця проживання та зняття з реєстрації місця проживання особи).

Щодо делегування органам місцевого самоврядування відповідного рівня повноважень із надання базових адміністративних послуг слід також зазначити таке. Пунктом 2 Плану заходів щодо реалізації Концепції реформування місцевого самоврядування та територіальної організації влади в Україні, затвердженого Розпорядженням Кабінету Міністрів України від 22 вересня 2016 p. № 688-p ${ }^{18}$, передбачалося до грудня 2016 року розробити проєкт Закону України «Про делегування органам місцевого самоврядування повноважень щодо надання деяких адміністративних послуг (щодо видачі, зокрема, через центри надання адміністративних послуг посвідчення водія на право керування транспортними засобами, державної реєстрації транспортних засобів)». Утім, зазначений запланований захід й до сьогодні залишився невиконаним. Ба більше, у Плані заходів із реалізації нового етапу реформування місцевого самоврядування та територіальної організації влади в Україні на 2019-2021 роки, затвердженому Розпорядженням Кабінету Міністрів України від 23 січня 2019 р. № 77-p ${ }^{19}$, питання делегування органам місцевого самоврядування повноважень із надання базових адміністративних послуг узагалі не значиться серед пріоритетів вищого органу виконавчої влади.

адміністративних послуг: Закон України від 10 грудня 2015 p. № 888-VIII. Офічійний вісник Украӥни. 2016. № 2. Ст. 49.

${ }_{18}$ Деякі питання реалізації Концепції реформування місцевого самоврядування та територіальної організації влади в Україні: розпорядження Кабінету Міністрів України від 22 вересня 2016 р. № 688-р. Офіційний вісник України. 2016. № 78. Ст. 2607.

19 Про затвердження плану заходів 3 реалізації нового етапу реформування місцевого самоврядування та територіальної організації влади в Україні на 20192021 роки : Розпорядження Кабінету Міністрів України від 23 січня 2019 р. № 77-р. Офіиійний вісник України. 2016. № 78. Ст. 2607. 
Водночас варто вказати й на позитивний досвід щодо делегування органами та підрозділами системи МВС України деяких адміністративних послуг (зокрема тих, що належать до компетенції сервісних центрів МВC) центрам надання адміністративних послуг при органах місцевого самоврядування, що здійснюється на виконання Розпорядження Уряду України від 16 травня 2014 р. № 523-р.

Наприклад, на початку листопада 2019 року стартував спільний пілотний проєкт Регіонального сервісного центру МВС у Київській області та місцевих органів влади Київщини щодо створення дієвої моделі співпраці фахівців сервісних центрів із адміністраторами ЦНАП. 4 лютого 2020 року Центр надання адміністративних послуг міста Українка Київської області видав перше посвідчення водія після його обміну без складання іспитів. Такий сервіс з'явився в переліку послуг цього ЦНАП завдяки налагодженій співпраці з Регіональним сервісним центром МBC в Київській області. I це не єдина послуга сервісних центрів МВС, яка віднині доступна в ЦНАП м. Українки. Крім реєстрації місця проживання, оформлення вітчизняних i закордонних паспортів, також можна:

- обміняти старе посвідчення водія на нове;

- відновити посвідчення водія у зв'язку із втратою чи викраденням;

- обміняти посвідчення водія у зв'язку зі зміною анкетних даних власника;

- зареєструвати новий транспортний засіб (без огляду ТЗ експертом);

- перереєструвати транспортний засіб у зв'язку зі зміною анкетних даних власника (без огляду експерта);

- зареєструвати газобалонне обладнання (без огляду експерта);

- здійснити вибракування транспортних засобів.

Новий метод роботи побудований на тому, що, з одного боку, деякі повноваження адміністраторів сервісних центрів МВС делегуються працівникам ЦНАПу, а з іншого - визначені фахівці територіального сервісного центру забезпечують дистанційну перевірку на відповідність поданих відвідувачами документів і швидке обслуговування споживачів. Така ефективна взаємодія установ органів публічної влади сприятиме децентралізації державних послуг, забезпечить максимальне ï наближення до споживачів і підвищить рівень якості обслуговування населення ${ }^{20}$.

${ }^{20}$ Надаємо державні послуги разом. Офіиійний сайт Вишгородської районної державної адміністраиії. URL: http://vysh.gov.ua/nadayemo-derzhavni-poslugy-razom/ (дата звернення: 07.05.2020). 
Сьогодні між РСЦ МВС у Київській області та місцевими органами влади Київщини, які надають адміністративні послуги через ЦНАП, підписано 5 Узгоджених рішень. Крім уже реалізованих планів із Українською міською радою, йдуть перемовини 3 Броварською райдержадміністрацією, Чабанівською селищною радою КиєвоСвятошинського району, Києво-Святошинською райдержадміністрацією та Іванківською райдержадміністрацією. Беручи до уваги, що нині по свій Україні діє понад 700 ЦНАП, а в системі МВС - 156 територіальних сервісних центрів, передбачається, що завдяки взаємодії із ЦНАП потенціал сервісних центрів МВС зросте в чотири з половиною рази, що значно підвищить рівень доступності та якості адміністративних послуг у сфері внутрішніх справ.

\section{ВИСНОВКИ}

Результати загальнонаціональних опитувань громадян України демонструють стійке зростання показників оцінки якості та доступності адміністративних послуг. Це, у свою чергу, свідчить, що реформа адміністративних послуг - одна $з$ найбільш системних і послідовних реформ України у сфері публічного адміністрування.

Важливий складник у системі органів публічної влади України, що потребує реформування на шляху реалізації ідеї сервісної держави, становлять органи й підрозділи системи МВС України. Разом зі сталим розвитком української державності, процесом соціалізації всіх сфер життєдіяльності суспільства закономірно відбувається еволюція соціально-правової орієнтації цих державних органів i механізму реалізації їхньої компетенції. Адміністративно-правові відносини щодо надання адміністративних послуг у сфері внутрішніх справ можна визначити як врегульовані адміністративно-правовими нормами суспільні відносини, що виникають у зв'язку зі зверненням фізичної чи юридичної особи приватного права до носія владних повноважень у зазначеній сфері - органу, підрозділу системи МВС України - 3 приводу прийняття ним адміністративного акта, спрямованого на забезпечення умов для реалізації прав, свобод і законних інтересів зазначеної особи або виконання покладених на цю особу законом обов'язків у сфері внутрішніх справ.

Зазначені відносини нині не позбавлені вад правового регулювання. Зокрема, законодавчо неврегульованими є адміністративні послуги у сфері внутрішніх справ, які надаються щодо об'єктів, обмежених у цивільному обігу. Крім того, залишаються нерозв'язаними питання правоздатності органів і підрозділів системи МВС щодо поєднання відповідної контрольно-наглядової діяльності 3 наданням адміністративних послуг. 
В умовах реформи 3 децентралізації значна увага приділяється створенню та організації якісної роботи ЦНАПів в об'єднаних територіальних громадах. Тому для формування нової системи надання адміністративних послуг в умовах децентралізації в Україні критично важливим чинником $\epsilon$, зокрема, подальше вивчення наявних моделей $\mathrm{i}$ кращих практик децентралізації надання адміністративних послуг, їх апробація під час реалізації пілотних проєктів добровільного об'єднання територіальних громад. Зокрема, делегування деяких адміністративних послуг у сфері внутрішніх справ ЦНАПам при органах місцевого самоврядування, що здійснюється на виконання Розпорядження Уряду України від 16 травня 2014 р. № 523-p, сприятиме децентралізації державних послуг, забезпечить максимальне їх наближення до споживачів і підвищить рівень якості обслуговування населення.

\section{АНОТАЦІЯ}

Статтю присвячено дослідженню шляхів удосконалення адміністративно-правових відносин щодо надання адміністративних послуг у сфері внутрішніх справ України в умовах децентралізації. Узагальнено результати досліджень оцінювання населенням України якості надання адміністративних послуг, що засвідчили системність і послідовність реформи системи надання адміністративних послуг в Україні. Наведено авторське визначення адміністративно-правових відносин щодо надання адміністративних послуг у сфері внутрішніх справ і сформульовано основні недоліки його правового регулювання. Проаналізовано правове забезпечення реформи децентралізації публічної влади в Україні, одним із пріоритетних завдань якої визначено забезпечення доступності та якості публічних послуг, зокрема, у сфері внутрішніх справ. Узагальнено позитивний досвід щодо делегування адміністративних послуг, що належать до компетенції сервісних центрів МВС, ЦНАПам при органах місцевого самоврядування. Наголошується, що ефективна взаємодія у сфері публічно-сервісної діяльності установ органів влади сприятиме децентралізації державних послуг, забезпечить максимальне їх наближення до споживачів і підвищить рівень якості обслуговування.

\section{ЛIТЕРАТУРА}

1. Циганов О.Г. Питання категоріально-понятійного апарату правового інституту «адміністративна послуга». Вісник Національного технічного університету України «Київський політехнічний інститут». Політологія. Соиіологія. Право : зб. наук. пр. Київ : НТУУ «КПІ», 2012. № 2 (14). С. 126-132. 
2. Оцінки населенням України якості надання адміністративних послуг (2015 рік, а також порівняння 3 минулими роками). Грудень 2015 р. Фонд «Демократичні ініціативи». URL: https://dif.org.ua/article/ otsinki-naselennyam-ukraini-yakosti-nadannya-administrativnikh-poslug-2015rik-a-takozh-porivnyannya-z-minulimi-rokami (дата звернення: 18.04.2020).

3. Якість надання адміністративних послуг в Україні: думка громадян, оцінка фахівців та зміни за 5 років. Фонд "Демократичні ініціативи». URL: https://dif.org.ua/article/yakist-nadannya-administrativnikhposlug-v-ukraini-dumka-gromadyan-otsinka-fakhivtsiv-ta-zmini-za-5-rokiv (дата звернення: 18.04.2020).

4. Про заходи щодо впровадження Концепції адміністративної реформи в Україні : Указ Президента України від 22 липня 1998 р. № 810/98. Офіиійний вісник Украӥни. 1999. № 21. Ст. 943.

5. Про схвалення Концепції розвитку системи надання адміністративних послуг органами виконавчої влади : Розпорядження Кабінету Міністрів України від 15 лютого 2006 р. № 90-р. Офіиіийний вісник України. 2006. № 7. Ст. 376.

6. За 10 років вінницький прозорий офіс прийняв понад 4,5 млн відвідувачів. Офіиійний сайт Вінницької міської ради. 10 жовтня 2018 p. URL: https://www.vmr.gov.ua/Lists/CityNews/ShowNews.aspx? $\mathrm{ID}=5446$ (дата звернення: 18.04.2020).

7. Про адміністративні послуги : Закон України від 6 вересня 2012 р. № 5203-VI. Офіиіийний вісник України. 2012. № 76. Ст. 3067.

8. Циганов О. Надання адміністративних послуг правоохоронними органами України: організаційно-правові аспекти : монографія. КиївВінниця : ТОВ «Нілан-ЛТД», 2018. 456 с.

9. Про схвалення Концепції реформування місцевого самоврядування та територіальної організації влади в Україні : Розпорядження Кабінету Міністрів України від 1 квітня 2014 р. № 333-р. Офіційний вісник Украйни. 2014. № 30. Ст. 831.

10.Про Національну поліцію : Закон України від 2 липня 2015 p. № 580-VIII. Відомості Верховної Ради Украӥни. 2015. № 40-41. Ст. 379.

11.Про затвердження Положення про дозвільну систему : Постанова Кабінету Міністрів України від 12 жовтня 1992 р. № 576. URL: http://zakon4.rada.gov.ua (дата звернення: 11.05.2020).

12.Коліушко I., Тимощук В., Банчук О. та ін. Корупційні ризики надання адміністративних послуг та контрольно-наглядової діяльності в Україні. Центр політико-правових реформ, Фонд «Демократичні ініціативи». Київ : Москаленко О.М. ФОП, 2009. 196 с.

13.Деякі питання надання адміністративних послуг органів виконавчої влади через центри надання адміністративних послуг : 
Розпорядження Кабінету Міністрів України від 16 травня 2014 р. № 523-р. Офіційний вісник Украӥни. 2014. № 45. Ст. 1193.

14.Проблемні питання децентралізації адміністративних послуг в Україні: аналітична записка Національного інституту стратегічних досліджень. URL: http://www.niss.gov.ua/articles/1797/ (дата звернення: 07.02.2019).

15.Про внесення змін до деяких законодавчих актів України щодо розширення повноважень органів місцевого самоврядування та оптимізації надання адміністративних послуг : Закон України від 10 грудня 2015 р. № 888-VIII. Офіційний вісник Украӥни. 2016. № 2. Ст. 49.

16. Деякі питання реалізації Концепції реформування місцевого самоврядування та територіальної організації влади в Україні : Розпорядження Кабінету Міністрів України від 22 вересня 2016 р. № 688-p. Офіиійний вісник Украӥни. 2016. № 78. Ст. 2607.

17.Про затвердження плану заходів 3 реалізації нового етапу реформування місцевого самоврядування та територіальної організації влади в Україні на 2019-2021 роки : Розпорядження Кабінету Міністрів України від 23 січня 2019 р. № 77-р. Офіиійний вісник Украӥни. 2016. № 78. Ст. 2607.

18. Надаємо державні послуги разом. Офіиійний сайт Вишгородської районної державної адміністраціï. URL: http://vysh.gov.ua/nadayemoderzhavni-poslugy-razom/ (дата звернення: 07.05.2020).

\section{Information about authors:} Tsyhanov O. H.,

Doctor of Juridical Sciences, Associate Professor, Chief Researcher of the 3d Department of Research Laboratory of Problems of Legal and Organizational Support of the Ministry Activities of the State Research Institute of the Ministry of Internal Affairs of Ukraine

4a, Ye. Hutsala Lane, Kyiv, 01011, Ukraine

Drozd V. H.,

Doctor of Juridical Sciences, Associate Professor, Senior Scientific

Associate,

Head of the 3d Department of Research Laboratory of Problems of Legal and Organizational Support of the Ministry Activities of the State Research Institute of the Ministry of Internal Affairs of Ukraine 4a, Ye. Hutsala Lane, Kyiv, 01011, Ukraine 